University of Montana

ScholarWorks at University of Montana

$1-1981$

\title{
Use of the Recreation Opportunity Planning System to Inventory Recreation Opportunities of Arid Lands
}

Perry J. Brown

University of Montana - Missoula, perry.brown@umontana.edu

B. L. Driver

USDA Forest Service, Rocky Mountain Forest and Range Experiment Station

Joseph K. Berry

Yale University

Follow this and additional works at: https://scholarworks.umt.edu/forest_pubs

Part of the Forest Management Commons

Let us know how access to this document benefits you.

\section{Recommended Citation}

Brown, Perry J.; Driver, B. L.; and Berry, Joseph K., "Use of the Recreation Opportunity Planning System to Inventory Recreation Opportunities of Arid Lands" (1981). Forest Management Faculty Publications. 43. https://scholarworks.umt.edu/forest_pubs/43

This Conference Proceeding is brought to you for free and open access by the Forest Management at ScholarWorks at University of Montana. It has been accepted for inclusion in Forest Management Faculty Publications by an authorized administrator of ScholarWorks at University of Montana. For more information, please contact scholarworks@mso.umt.edu. 


\title{
Use of the Recreation Opportunity Planning System
}

\section{to Inventory Recreation Opportunities of Arid Lands'}

\author{
Perry J. Brown, B. L. Drlver, and Joseph K. Berry ${ }^{2}$
}

\begin{abstract}
Recreation opportunicy planning, which is betng adopted by some land wanagewent agenctes for recreation input to land management planning, is reviewed for 1 ts applicability to arid land situations. Particular attention 1s given to the inventory and analyais phases of the syatem and to what we have learned bout fts implementation during Ita development.
\end{abstract}

Recreation use of arid lands in the USA Is growing rapldly. Those lands provide many recreational opportunities which range from primitive and unconfined forms of recreation through those forms provided at tourlst resorts. They also provide unique recreational opportunities in distinctive landacapes with widely appealing and rather predictaile climates. Pressures of Increasing use have caused arid land managers to Intensify their recreation planning and management activities on areas such as the deserts of southern Californta and western Arizona and the canyonlands of southern Utah. These resource managers, like thetr counterparts in more temperate environments, need planning and management techniques which enable better assessment and evaluation of recreation resource capabilitles, integration of recreation with other resource uses, and management of the resources for recreation. Recreation opportunity planning, using the recreation opportunity spec-

${ }^{1}$ Paper presented at the workshop on Arid land resource inventories: Developing cost-efficlent methods. LaPaz, Mexico. November 30-December 6,1980 .

Development of the recreation opportunity planning system and assoclated computer programs were funded in part by Richard Driscoll's Resource Evaluation Techniques project (RM-4151) at the Rocky Mountain Forest and Range Experiment Station, USDA Forest Service, Ft. Collins, Colorado 80526.

${ }^{2}$ Perry J. Brown is Professor and Head of Resource Recreation Management, Oregon State University, Corvallis, Oregon; B. L. Driver is Recreation Project Leader, Rocky Mountain Forest and Range Experiment Station, USDA Forest Service, Fort Collins, Colorado; Joseph $k$. Berry is Assistant Professor of Forestry, School of Forestry and Environmental Studies, Yale Untvers1ty, New Haven, Connecticut. trum concept, can help meet these needs of planners and managers of arid lands.

Recreation opportunity planning is an activIty within the recreation production and evaluation proceas and it enables the rational allocation and management of recreation resources. To gain a more complete understanding of recreation opportunity planning we w111 review this production and evalustion process to show where recreaton opportindty plannine fita within $1 t$.

At a natlonal outdoor recreation outputs workshop conducted at harpers Ferry in West Virginia, an at tenpt to define this production and evaluation process was made. 3 A simplifled diagram of this process 18 shown in figure 1 and is briefly discuased below.

The production of recreation opportunities begins with primary resources of land, labor, and capital. These resources are used in management actions such as bullding tralls, congtructing campIng factlities, grazing domestic livestock, and providing sanitation and Information services. Each action has an influence on the type, amount, and quality of recreation opportunity that is provided. In combination such actions (or non-actions) create the environment for recreation and thus the activity opportunities available and the probable experiences that w11l be realized. They, therefore, create the recreation opportunttles supplied or produced, In this way, management actions are used to transform basic resources into recreation opportunities which recreationists then use to praduce specific recreation experiences.

${ }^{3}$ Driver, B. L. and D, Rosenthal. The outdoor recreation production process. Unpublished report. USDA Forest Service, Rocky Mountain Forest and Range Experiment Station, Fort Collins, Colorado. 


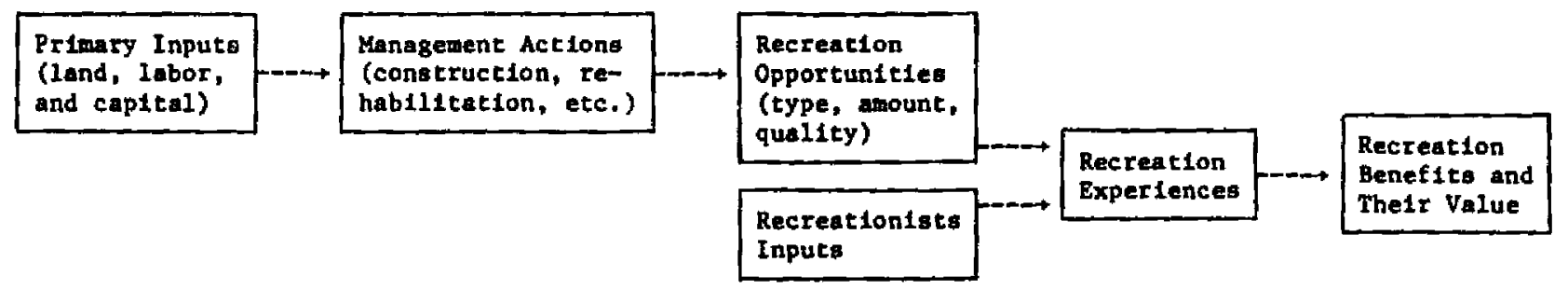

Figure 1,--The recreation opportunlty production and evaluation process.

The recreationists' consumption of these recreation opportunities gives the resson for their production and provides an indication of the factors to be considered in defining the opportunities to be produced. In their congumption behavior (Driver and Tocher 1970, Brown, Dyer, and whaley 1973. Hendee 1974, Driver and Brown 1975), recreatlonists are aeen as coming to an area with specific expectations and desires for spectflc types of satiafaction. They engage in recreation activities at areas where they belleve the combination of resource, social, and managerial characteriatics that will enable them to resllze their desires are offered. When they leave the area, they leave after having had experiences that, if satiafactory, w111 lead to subsequent personal and societal benefits.

The evaluation phase of the process defines the boctal worth of recreation opportinities and subsequent recreation experiences. It is used to identify and quantify the economic and non-economle individual and societal benefits of recreation opportunties and expertences.

Recreation opportunicy planning provides a rational framework for determining how recreation opportunities should be produced, It focuses on the setings for recreation that are provided by management and that are used to deliver recreation opportunities to recreationists. It is a relatively new planning framework that is based on making the recreation opportunfty spectrum an operational concept."

\section{INVENTORY FOR RECREATION OPPORTUNITY PLANNING}

A recreation opportunity is the chance to engage in a recreation activity in a specific setring to realize a desired recreation experience. Recreation opportunity planning generates demand and supply information about the type, quanticy, and

"Butlding on Ideas expressed by J.V.K. Wagar (1951), W.R. Burch, Jr. (1964), S.R. Tocher, J.D. Hunt, and J.A. Wagar (1965), and J.A. Wagar (1966), Driver and Brown (1978) and Clark and Stankey (1979) have provided the framowork for making the recreation opportunity spectrum concept operational through recreation opportuntty planning. quality of these recreation opportunities for use in resource allocation and management decision making. A primary feature of this planning is its arraying of the types of recreation opportunities long a epectrum. This recreacion opportunity opectrum, at the most aggregated level, usually has been divided into five classes as shown in figure 2 (Driver and Brown 1978). The cemi-prim1tive class often has been divided into two subclasses, semi-primitive motorized and semi-primitive non-motorized. This subclassification 1llustrates that any of the spectrum clasges can be subdivided to weet the needs of decision makers.

Currently the most widely applied componente of recreation opportunity planning are the inventory and analyais phases, 5 These portions of the planning system, with emphasis on arid lands, are the focus of the remainder of this paper.

The recreation opportunity Inventory enables Identification of current and potenclal types, amounts, and qualities of recreation opportunity (Brown, Driver and McConnel1 1978). It beg1ns with Identification of the attributes of the recreational setting which need to be assessed. Those attributes which must usually be considered are:

1. roads, trails, and other transportation - Eeatures

2. bulldings and other man-made structures

3. sources of man-made sound

4. relatively irreversible evidences of man

5. renewable resource modifications

6. vegetation patterns and types

7. soil types

8. topographic relief

9. water bodies and channels

10. wildlffe species, numbers and patterns

11. specific natural features enabling recreation activities

Modern- Roaded Sem1-

Urban Rural Natural Primitive Primitive

Figure 2.--A common division of the recreation opportunity spectrum.

${ }^{5}$ An overview of the entire recreation opportunity planning system occurs in Brown (1979). 
12. racreation user numbers, densities, and behaviore

13. recreation management activities being practleed

14. other land usea

Data on these attributes are used in recreation opportunity planning in several ways. For example, the planner often vants to knov which recreation experiences (such as finding solitude, affllating with fanily or friends, or self-testIng) most likely can be realized at the preaent time by recreating on spectfic tracts of land. To obtain this information, data about transportation features, bulldings and other man-made structures, sources of man-made sound, relatively irreversible evidences of man, renewable resource modifications, recreation uge, and recreation management activ1tieg are comblned. These data are then analyzed using specific standarda which enable zoning a tract of land Into one of the recreation opportunity spectrum classes. Each of these classes has inherent in it higher probabilities for some experiences than for other experiences. Alternatively, if the planner's interest is in the most probable potential recreation experiences, the planner can analyze data on the same attributes as for current fecreation experiences, except for the last two, both of which define current conditions, not potential conditions. $0 \mathrm{r}$, If the planner is Interested in 1dentifying the potential for apecific recreation activities, the requirements for each activity must be looked at. Recreation opportuntty inventory can help do this by providing information about recreational features, such as slope, snow condftions, water bodies and wildlife.

The planner's determination of quantity of each recreation opportuntty avallable requires data on vegetation, solls, water, wlldlife, specific recreational features, and recreational facilities. Based upon the ability of each attribute to support recreation, a fudgment is made regarding the quantity of each recreation opportunity avallable. Determination of the quality of each recreation opportunity is most dependent upon information about specific recreational features and facilities.

Once information on current and potentlal recreation opportundty type, amount, and quality is assembled, the planner can determine production possibilities for different tracts of land. This can lead to development of resource use alternatives in either a single or multiple use framework. 6

To date most use of recreation opportunity planning has occurred on temperate and semi-arid

\footnotetext{
${ }^{6}$ A more complete description of how to do recreation opportunicy planning as part of total land management planning will be available soon in Chapter 500 of the USDA Forest Service Land Management Planging Handbook (FSH 1909.12).
}

forest environments of North America. Only a few applications have been wade in arid grass and desert lands (Brown, Driver, Bruns, and HcConnell 1979). However, our experlence w1th recreation opportunity planning, and particularly the inventory and analysis phases, suggesta that the syotem is widely applicable to arid lands. Also, as recreation opportuntty planning has been applier, we have learned how $1 \mathrm{t}$ can be Improved when applied to arid and non-arid lands.

What have we been learning? One thing is that the attributes of the land and 1ts management that need to be inventorled are the ome for all types of landscapes. That 1s, for all lands we need to inventory the same kinds of features.

Another thing we have learned la that while the features to Inventory do not vary by landscape, many of the standards that make these attributes uaeful in different settinga do vary. For example, one of the criteria for delineating recreation opportunities is remoteness of the area from sights and sounds of wan. In general this has been operationalized as a digtance from roads and tra1].s having motorized use. ${ }^{7}$ In the forested areas of the central Rocky Mounteing a distance of three miles is gufficlent to delineate an area providing opportunity for primitive and unconfined recreation (Brown et al 1978). In the more dense1y stocked forests of the Pacific Northwest and the Eastern U.S.A., a otandard of 1 egs than three miles is sufficlent. And, In the grasslands and deserts of the Southwestern U.S.A. and northern Mexico, a distance of greater than three miles, possibly as many as five or six miles, is sometimes necessary to provide the same recreation opportunity. This greater distance is necessary to diffuse the slghts and sounds of man where there are few natural obstructions, as across a relatively flat grassland. This means that for both grassland and desert environments having little topographic relief larger areas are needed to provide primltive and unconfined recreation opportunfties than are needed for forested environments. Where the topography is more varled, as in a canyonlands type landscape, the distance standards used on ar1d environments appear to be closer to those used for forest landscapes, and thus smaller areas can provide the same recreation opportunities as larger areas of other arid lands.

Another finding has heen that the quantities of many recreation opportunities are lower in arid

\footnotetext{
${ }^{7}$ Waterways with motorized use and railroads are fncluded. Also, non transportation considerations dealing with vialbility or audability of human works are used where distance from transportation routes does not indicate the degree of remoteness necessary. Data necessary to identify remoteness comes from inventory of transportation and other man-made features, The data are evaluated using specific remoteness standards for each recreation opportunity spectrum class.
} 
environments than in temperate enviromments. This 18 particularly apparent in comparing temperate forests with arid forests, grasalands, or deserts. For example, capacity is ifmited for primicive and semi-primitive recreation opportunities because of limited screening of other people by vegetation. Quantity is also limfted for more developed and motorized recreation opportunities becauge of lack of moisture, and 1 ts subsequent consequences, in arid landscapes. Additional potential $11 \mathrm{mits}$ on quantity and impacts of recreation on arid environments have been Identifled by Hunt (1977).

Another, but more subtle thing which we have learned is that some attributes used to define the quality of recreation opportunitles differ between ar1d and temperate anvironmente. For example, cl1metc factora are Important in all landscapes but coolnese of the temperature sems to be particularly important attribute in arid environments used for recreation.

Another thing that we have learned about recreation opportunity planning is that once a planner adopts the logic of $1 \mathrm{t}$, it $1 \mathrm{~s}$ relatively easy and efflctent to use, whecher $1 \mathrm{t}$ is used in a temperate or arid environment. The logic is explicit, the criterla for identifying recreation opportunity areas are held to a minimum, and one can select the required precision for data collection and analysis based on the level and kind of decision to be made.

We have also discovered that when recreation opportunicy planning is used on a regional or national scale, computerized data processing is desirable. Therefore, we have begun to adapt a general cartographtc mapping system, called the Map Analysis Package (MAP) (Tomlin and Berry 1979) to our purposes (Berry and Brown 1980).

The MAP computer sof tware package consists of a system of primary computer operations which can be Iinked to produce a new synthesis of mapped data. It presently employs a grid-cell data structure for all analytical operations, though data may be input in many forms. Many primary computer operations are avallable in the MAP progran although only a few of ther were necessary for our application in recreation opportunity planning.

The cartographlc model for addressing recreation opportunities enables generation of maps and tabular data on current and potential recreation opportinities. It presents the advantages of allowing large quantities of data to be stored and retrieved easily, and it enables preparation and reprocessing of maps much more quickly than if they are produced by hand drawing.

Our recreation opportunity cartographic model was developed and tested using a hypothetical data set. It is now belng applied to an arid lands sit-

${ }^{\text {MAP }}$ is currently operational on IBM computers and is beling adapted co CDC-CYBER computers. uetion in the Steeng Mountain area of eastern Oregon. Illustrative of the output of this recreation opportunity cartographic model are figures 3 and 4 which show current and potential recreation opportunitles, respectively, for a 4500 hectare area using the hypothetical data set.

In producing figure 3 (current recreation opportunities), information about phyoical resources and their alteration by humans was combined with information about present recreational use and management activities. Figure 4 (potential recreation opportunities) was produced using only information about physical reaources and thelt alternation by humane. In comparing these two figures we can see that proaent use and managemant chrracter1otice have in effect upon the ewount of beni-priw1tive and modern-urban opportunities that are presently provided. Presently lese semi-primitive and more modern-urban opportunities ere provided than would be determined by the churacter of the land base lone.

Other thinga learned from our current appilcatlons of recrestion opportunity planning are that: (1) It can be easily adapted by different agencies, such as the U.S. Forest Service and the Bureau of Land Management, and thereby help establish a common recreation planning and management language

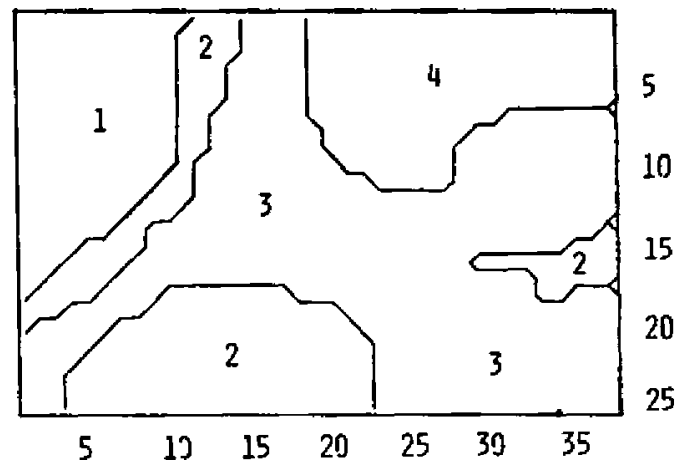

Figure 3.--Current recrearion opportunities: (1) Modern-Urban, (2) Rural, (3) Roaded Natural, and (4) Semi-Primitive.

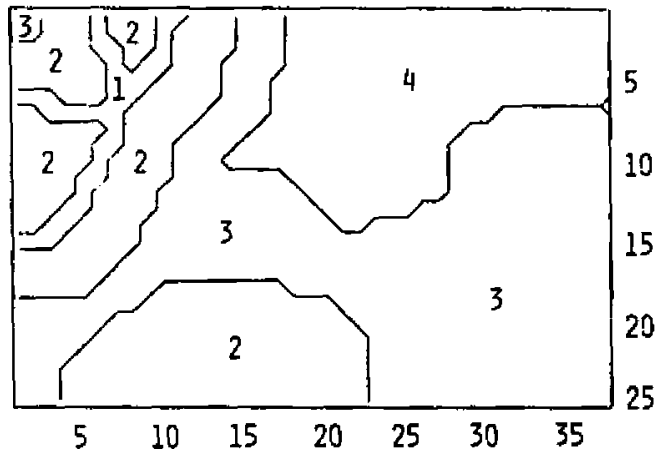

F1gure 4,--Potential recreation opportunitiea: (1) Modern-Urban, (2) Rural, (3) Roaded Natural, and (4) Semi-Primftive. 
ecrose agencies; (2) the logic of the planning systera is incultively acceptable both to resource plannere and to the public, such as when it 1s explained in public involvement raview sesatons; (3) the aysten provides laproved bases and means for evaluating the 1tpacts of different manageaent activities on the type, quantity, and quality of recreation opportunities thet can be provided; and (4) the concepta about the recreation opportunity apectrum which are uged in recreation opportunity planning can also terve as guidelines for recreation resource management.

\section{COACLUSION}

Recrestion opportuntty planting hes been developed to provide a framework for making recreation Inpute to land management planning. It is a planning procese which fite within the broader tecreation opportunity production and eveluation process and helps in making rational declatons about the allocation and management of recteation recources.

Our experience in using recreation opportuntty planning, particularly its inventory and analysis phases, has indicated that it 1a widely applicable to arid land oftuations. Spectelc elements of the planning process do change, however, when it is applied to arid lands. For example, while the criteria for identifying types of recreation opportuntty rematn the same, cheir standards change when one moves from temperate to arld landacapes. Also, quantities of opportunity provided are often lower In arid environments than in temperate environments, and sometimes the factorg considered in assessing quality of opportuntty are different between arid and temperate environments.

A recent effort in development of tools for recreation opportunity planning has been development of the cartographic model which enables eff1cient storage, retrieval, and mantpulation of mapped and tabulated data. This model is presently being tested in an arid lands situation in eastern oregon.

Because recreation opportunlty planning, including its inventory and analygis phases, fits within the general production and evaluation process that has been defined for recreatlon, and because it is a map based system that allowg visuallzing the Impact of management actions on the type, amount, and quality of recreation opportunity provided, we feel the system has conslderable promise for the recreation component of land managenent planning. Since both the USDA Forest Service and the USDI Bureau of Land Management are adopting the process, we expect its use to become even more wideepread. It appears to be quite applicable to both temperate and arid landacapes.

\section{LITERATURE CITED}

Berry, J. K., and F. J. Brown, 1980. A cartograph1c model for assessing outdoor recreation opportunity: In Proceedings of the Internatlonsl user' a conference on computer mapping hardwate, software, and data bases. Harvard Univeraity, Cabridge, Massachusetto.

Brow, P. J. 1979. The opportunicy spectrum: Techniques and implications for resource planning and coordinat'on. 'p. 82-87. In Disperaed recreation and natural resource management. College of Natural Resources, Utah State University, Logan, Utah.

Broun, P. J., B. L. Driver, D. H. Bruns, and C. McConnell. 1979. The outdoor recreation spectrum in wildand recreation planing: Development and application. p. 527-538. In Proceedinge of the rectention plenning sympostum, Volume II. American Soclety of Civil Eng1neere, Hew York, R.Y.

Brown, P. J., B. L. Driver, and C. KeConnet1. 1978. The opportunity epeetrun concept and behevioral information in outdoor recrestion cupply inventoriea: Background and application. p. 73-84. In Integrated Inventories of renwable nacural recources: Proceedinge of the workohop. USDA Foreat Service General Technlcal Report RM-55. Rocky Mountain Forest and Range Experiment Stat1on, Fort Collins, Colorado.

Brown, P. J., A. A. Dyer, and R. S. Whaley, 1973. Recreation resesrch -- vo what? Journel of Le loure Research $5(1): 16-24$.

Burch, W. R., Jr. 1964. Two concepts for guiding recreation manggement decisions. Journal of Forebtry 62(10):707-712.

Clark, R. N. and G. H. Stankey. 1979. The recreation opportunity spectrun: A framework for planning, management, and research. USDA Foreat Service General Technical Report PNH-98. Pacific Northwest Forest and Range Experiment station, Portland, Oregon.

Driver, B, L., and P. J. Brown, 1975. A socialpsychological definition of recreation demand, with Implications for recreation resource planning. p. 64-88. In Assess 1ng demand for outdoor recreation. National Academy of Sclences, Washington, D.C.

Driver, B. L., and P. J. Brown. 1978. The opportunity spectrum concept and behavioral information in outdoor recreation supply inventories: A rationale. P. 24-31. In Integrated inventorles of renewable natural resources: Proceedings of the workshop. USDA Forest Service General Technical Report RM-55. Rocky Mountain Forest and Range Experiment Station, Fort Collins, Colorado.

Driver, B. L., and S. R. Tocher. 1970. Towarả a behavioral interpretation of recreational engagements, with implications for planning. p. 9-31. In Elements of outdoor recreation planning. Univergity Microfilms, Ann Arbor, itichigan.

Hendee, J. C. 1574. A multiple satisfaction approach to game management. Wildlife Society Bulletin 2(3):104-113.

Hunt, J. D. 1977. Recreation 1mpacts on ar1d forest lands. p. 92-97. In Proceedings of the Soclety of American Foregters Annual Convention. Soclety of American Foresters, Washington, D.C. 
Tocher, S. R., J. A. Hagar, and J. D. Hunt. 1965. Sound management prevente worn out recreation a1tee. Parka and Recreation 48(3):151-153.

Tom11n, C. D*, and J. K. Berry, 1979, A mathematlcal structure for cartographic wodeling In environmental anslyals. p. 269-283. In Proceedings of the American Congress on Sur- veying and Mapping, 39th Meeting. Awerican Soclety of Photogrametry, Fal1s Church, Virginla.

Hagat, J. A, 1966. Quality in outdoor recreation. Trends In Parks and Recreation 3(3):9-12.

Hagar, J. V. K. 1951. Some mafor principles in recreation land use planning. Journal of Forestry $49(6): 431-435$.

Restian: Se ravise, respecto a su apllcabilidad a conas fridas, la planeación de 1a Oportunidad Recreative, la cual esta siendo adoptada por algunas agenclas relactonadas con el anejo de terras con objeto de determinar el insuwo recrentivo en 1 planeación para el anejo de tierras. Se da particular atención a las faser de inventario y de anklisis del sistese y a 10 que hamos aprandido relativo ou luplementacion en el curso de su deserrollo. 


\title{
Large Area, Low Cost Resource Inventories -
}

\section{Canadian Programs, Methods, and Costs'}

\author{
D.M. Welch, T. Plerce and E.B. Hiken ${ }^{2}$
}

\begin{abstract}
The Canada Land Inventory, Ecologlcal Land Survey and the Horthern Land Uae Inforwation Serles are described. For large areas and at ocales typlcally enaller than $1: 100,000$, these interdisciplinary inventortes cost between $\$ 1.00$ and $\$ 16.00 / \mathrm{km}^{2}$. Ecological Land Survey is. most recomended for developing an environmental data base for a wide variety of interpretatione.
\end{abstract}

\section{INTRODUCTION: SOCIO-POLITICAL BACKGROUND}

"Canada is a few acres of onow and not worth a soldier's bones." So Voltalre is reputed to have written in the $1760^{\prime} \mathrm{s}$. A century later Canadian Industrialist suggested that we had become "hewers of wood and drawers of water." The two saylngs reflect traditional and yet conflicting views of our place In the scheme of things - first a wasteland and then a resource-rich colony. Only since World War II have we developed fror exploitation to resource management and the need for nat lonal and regional pollclee designed to yield maximus benefits to all social and economic pectors.

It 1 s common nowadays to require of resource projects that environiental and soclal impacts be considered and that multi-resource developaent opportunitles be taken in hand. Th1s trend focusges on hollstic planning and management, on inter- and Intra-reglonal comparlsons of environments, resource bases and socleties, and on the consequent need for a multi-resouce data base upon which to Influence public thlnking, establish policy and base management declatons. Several methods for collecting such data have evolved in Canada. They are presented to this conference in the bellef that our hinterland of fers the same challenges to resource inventory as do arid lands.

\section{Canadian PERSPECT [UES}

The majority of 23 million Canadlans live in urban and rural areas in the south. Areas which exceed Mexico, such as the Northwest Territorles, contain a scant fraction of the population (table 1; fig. 1).

\footnotetext{
lPaper presented at the Arld Land Resource Inventorles workshop, La Paz, Mexien, Nov.30 Dec.6, 1980 .

2David Welch, Tom Plerce and Ed When are research officers of the Lands Directorate, Environment Canada, Detawa K1A 0E7, Canada.
}

Intensive land uses, such as living, moving and food, wood and mineral production occupy onetanth of Canada (table 1). Other neasurable wee, such as mineral exploration, parks and reserves account for one-fifth of our land and freshuser. The renelinder is largely "left" to water catchwent, widilfe production and migration, native hunting, trapplng and flshing, and varlous formo of wilderness recreation, although many contemporary and future economic developents are under consideration. Examples are oll and gas exploration, plpeInes, natlonel parke, cowaerclal hunting of whales and of terrestrial and warine furbearers, and northern highways.

\section{resource plannimg in canada}

Land uge and resource plannlng and anagenent In Canada are aubject to several furladictlons. Any region or resource sector bay fall whin aunictpat,

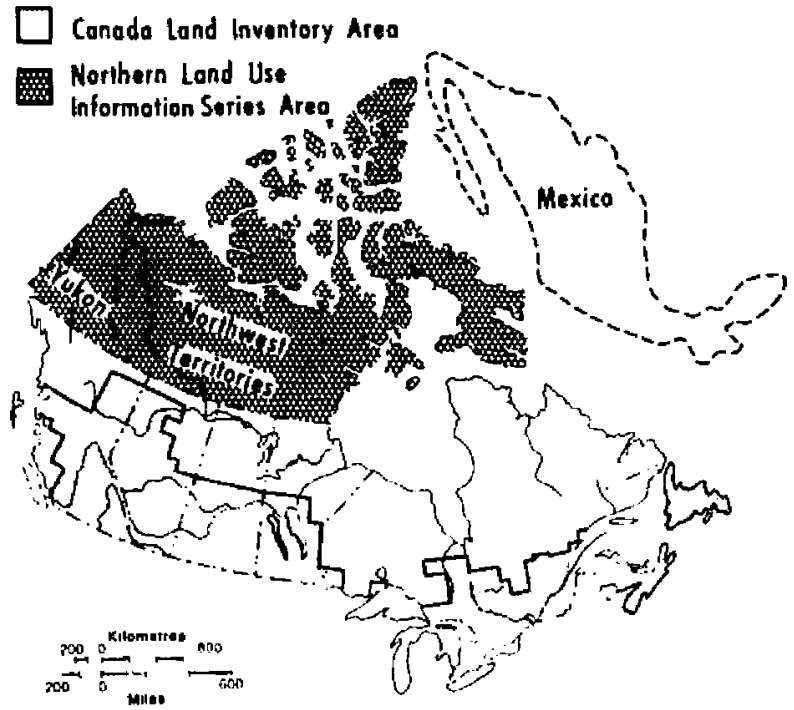

Figure 1.-- Canadian Perspectives. 